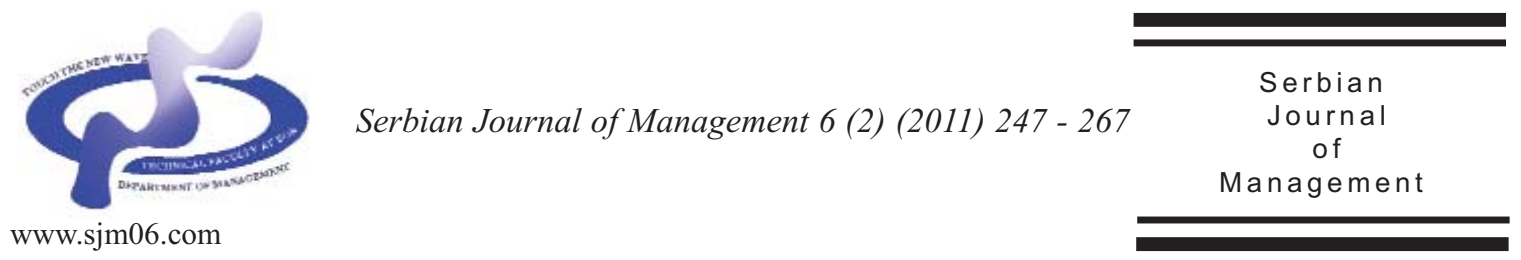

\title{
STAKEHOLDERS' PERCEPTION OF THE INDEPENDENCE OF STATUTORY AUDITORS IN NIGERIA
}

\author{
Semiu Babatunde Adeyemi ${ }^{a^{*}}$ and Kehinde Opeyemi Akinniyi ${ }^{b}$

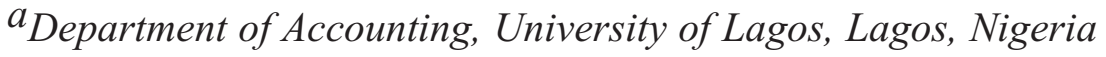

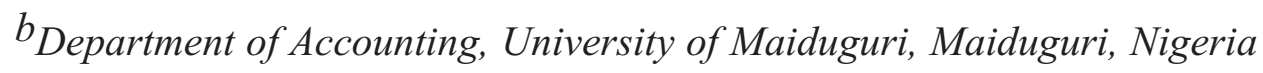

(Received 12 June 2011; accepted 18 September 2011)

\begin{abstract}
Towards the end of the nineteenth century, there were celebrated cases of corporate frauds and financial misappropriation in corporate giants. The series of frauds have left a sense of doubt about the "unbiasedness" of external auditors to render an attest function on the credibility of published financial statements. In this light, this research sought to empirically investigate into the perception of auditor independence in Nigeria. A cross-sectional survey was conducted on the opinions of randomly selected lecturers of auditing, practising auditors, stockbrokers, shareholders and managers. Primary data was extensively relied upon. In addition to the primary data, secondary data from annual reports were also used. The data collected were used to answer research questions and test hypotheses. Test of hypotheses was performed using Pearson Correlation and Kendall's measure of concordance at a 0.05 level of significance. The outcome of the tests showed that the selected respondents perceived size of audit fee as the most influencing factor, capable of deterring auditor independence in Nigeria. It was also observed that existing laws were obsolete and need to be updated to make them relevant.
\end{abstract}

Keywords: statutory auditor, independence, stakeholder

\section{INTRODUCTION}

In Abbott et al. (2003), Jensen and Meckling (1976) suggested that demand for auditing stems from a desire to reduce managements shirking, resulting from information asymmetries, which arises from the separation of ownership and control. Ojo (2009) expressed that the involvement of external auditors could contribute to corporate governance and address the expressed agency problem, because the auditor can facilitate a situation where by managers are encouraged or compelled to be

\footnotetext{
* Correspondingauthor: sbaadeyemi@yahoo.co.uk
}

DOI: $10.5937 / \mathrm{sjm} 1102247 \mathrm{~A}$ 
held accountable. Beattie and Fearnley (2002) pointed out that financial audit remains an integral part of corporate governance.

Despite the prominence ascribed to external audit function, the sovereignty of the external auditor is an issue currently attracting scholarly scrunity. Mautz and Sharaf (1961) in Arnold et al.(1999) noted that, auditors must be constantly aware of factors that affect the audit environment which can influence or harm their independence in other to ensure confidence of investors. Supporting this statement, Xu and Wang (2008) reiterated that independence has long been recognized as the most important defining characteristic of the public accounting profession.

However, the spate of corporate failure in developed and developing economies all over the world, have stirred the quest to ascertain if the failures are associated with the independence required of statutory auditors. Byrne (2001), as well as Ayvaz and Pehlivanli (2010) expressed that objectivity or "independence of mind" is essential for the exercise of professional judgement, which has continued to be an important topic. In the same vein, Callaghan et al. (2009) identified auditor independence as a necessary condition for effective auditing. In the light of these statements, this research sought to empirically examine the independence of statutory auditors in Nigeria, with emphasis on same selected audit firms.

\subsection{Statement of the Problem}

Adelaja (2009) expressed that credible financial information is vital to the growth of any economy; also auditors are expected to be independent and objective in the discharge of their responsibilities. Gallegos (2004) was of the view that the report of external auditors in corporate financial statements is seen as providing key assurance to the interest of shareholders.

O'Connor (2006) stated that one of the most vexing problems in the financial world today, is the emphasis placed on ensuring the independence of external auditors as a result of recent economic scandals. Beattie \& Fearnley (2002) expressed that after the collapse of Enron, it was generally believed that rendering of non-audit services compromised the independence of external auditors. An extract from the website of Institute of Chartered Accountants England and Wales (ICAEW) (2009), reiterated that the independence of statutory auditors is a rather complex issue.

In the real world, when business entities go out of business, the consequences are usually enormous. The oversight function of the auditor is placed under scrutiny when a business whose financial statement once showed no indication of going out of business suddenly becomes bankrupt. As a follow up to the oversight function, the independence of the auditor also appears to be in doubt. On this premise this research focuses on the possible challenges which may be affecting the independence of external auditors in Nigeria.

\subsection{Aim and Objectives of the Research}

The primary objective of this research is to elucidate on the independence of external auditors in Nigeria. This was achieved by:

1) Appraising the factors that are capable of influencing the independence of auditors.

2) Evaluating the perception of the Nigerian public, concerning the 
independence of external auditors.

3) Identifying the factor that is most capable of influencing the independence of statutory auditors in Nigeria.

\subsection{Research Questions}

Supporting the research objectives set out above, the following questions were advanced and answered:

1) How does audit fee affect the independence of auditors?

2) How does audit tenure affect the independence of external auditors?

3) How does non-audit service influence the independence of external auditors?

4) Are there specific pronouncements which define the independence of external auditors in Nigeria?

5) Do audit firms in Nigeria make returns of their financial activities?

6) What threats are peculiar to the independence of external auditors in Nigeria?

7) Does any relationship exist between audit tenor, and audit fees?

8) Do annual reports contain information of non-audit services performed by auditors?

\subsection{Research Hypotheses}

The following research hypotheses flow from the research questions that were raised;

Hypothesis One: Xu and Wang (2008), and Callagham et al. (2009) argued that independence of external auditors is mired by performing non-audit services. Gul et al. (2007) however suggested that non audit fees may not prejudice the independence of auditors where the audit engagement is not for a short period of time.
These positions form the bases of the hypothesis that:

Ho1: There is no correlation in the perception of respondents, that fees from the performance of non-audit services can deter the independence of auditors in Nigeria.

HI1: There is a correlation in the perception of respondents, that fees from the performance of non-audit services can deter the independence of auditors in Nigeria.

Hypothesis Two: Klimentchenko (2009) was of the view that it is likely for an auditor who has been auditing a client for several years to let down on his guard. With regards to tenure, Davis et al. (2000), suggested that there existed a significant negative relationship between tenure and absolute analyst forecast errors. With respect to auditors in Nigeria, the hypothesis below was tested.

Ho2: There is no significant correlation in the opinion of respondents that prolonged audit tenure can impair the independence of statutory auditors.

HI2: There is a significant correlation in the opinion of respondents that prolonged audit tenure can impair the independence of statutory auditors.

Hypothesis Three: In an effort to understand the opinions expressed by respondents, a ranking was done to test the hypothesis that;

Ho3: There is no significant agreement in the opinion of respondents on the ranking of factors capable of influencing the independence of statutory auditors in Nigeria.

HI3: There is a significant agreement in the opinion of respondents on the ranking of factors capable of influencing the 
independence of statutory auditors in Nigeria.

Where Ho: is the null hypothesis and HI: is the alternative hypothesis.

\section{SIGNIFICANCE AND THE CONCEPT OF THE STUDY}

This research dwells on the independence of auditors particularly within the context of listed companies in Nigeria. The findings of this research are expected to contribute to existing body of knowledge. Practicing auditors in Nigeria are anticipated to become more informed of the intricacies surrounding auditor independence. The academic community will also benefit enormously from the outcome of this research.

\subsection{Scope and Limitation of the Study}

This research centers on the independence of external auditors within the context of listed companies in Nigeria. This research excludes audits of non listed companies and internal audit function of companies. The outcome of this research is based on what is obtained in Nigeria. It is likely that the opinions expressed may not represent the views of every Nigerian; however these variations are not expected to adversely influence the findings of this research.

\subsection{The Concept of Auditor Independence}

The initial concept of auditor independence was primarily of British origin, in the 19th century, where auditors doubled as book keepers (Baker, 2005). Aderibigbe (2005) views independence as an emotive word serving as a banner for freedom, integrity and all that is good. Auditor independence according to Dictionary of International Accounting Terms (2001) infers a state of impartiality required of auditors who should have no personal or financial involvement with a client. Louwers et al. (2007) expresses independence as a mental attitude and physical appearance which portrays the auditor as being uninfluenced by others in judgment and decision. This can be sustained by avoiding financial connection that makes it appear that the wealth of the auditor depends on the outcome of the audit and management connections that makes the auditor appear as if he is involved in management decisions. As a key ingredients of audit quality Gray \& Manson (2000) and Hayes et al. (2005) described independence as a position required in other to take an unbiased viewpoint in the performance of audit tests, analysis of results and attestation in the audit report. Despite all the definitions, and descriptions of auditor independence, Whittington \& Pany (2004) concluded that auditor independence is relative and not absolute. According to Tairu (2009), auditor independence comprises of programming independence, investigation independence, and reporting independence. Of these three components, reporting independence is the most likely to be influenced by the directors of a client company. This is the foci of this research. The independence of auditors is seen as a means and not an end in itself (McGrath,et al., 2001). Consequently, Smith (2003) opined that the prime responsibility of maintaining independence and objectivity rests with the auditor.

\subsection{Threats to Auditor Independence}

From the foregoing, an auditor is 
expected to be free from undue influence which may affect his opinion about the state of affairs of his client's business. The auditor is required to be independent and also be seen to be independent by stakeholders of the entity he is reporting on.

Threat according to Chambers Dictionary (2002), implies a source of danger. It may be perceived that threat to independence connotes circumstances that can jettison the "unbiasedness" of the auditor. Threat to auditor independence have been broadly categorized as one or a combination of selfinterest, self-review, advocacy, familiarity (or trust) and intimidation threat (ICAN Membership Handbook 1999; et al., 2001; Millichamp 2001; Adeniyi, 2002; Report, 2003; Hayes et al., 2005). The elements that are likely to give rise to these threats include tenure (Geiger \& Raghunandan, 2002), rendering of non audit services (Xu \& Wang, 2008), ability of managers to influence the compensation of auditors (Yost, 1995), size of the audit firm (Salehi \& Mansoury, 2009), and strength of audit committee (Abbott et al., 2003). Other factors according to Abubakar et al. (2005) include; highly competitive audit service market, large size of audit fees and non existence of audit committees.

\subsection{Tenure of Audit}

Tenure of audit refers to the number of years audit firms or engagement partners have spent on the audit of a particular client. There have been heated debates on the relevance of tenure to the independence of auditors. Klimentchenko (2009) was of the opinion that if an auditor (or a representative of the audit firm) reviews the financial information of a client, year-after-year, he becomes familiar with the business of his client, develops a desire to maintain good rapport with the manager of the client's business and thereby losing his impartiality. Consequently, Davies et al. (2000) examined some arguments for and against how tenure influences the independence of auditors. The arguments against presupposes that the longer an audit firm retains a client, the less able it is, to maintain objectivity. On the contrary, the arguments for, suggested that the longer an auditor is on an engagement the better will be, his understanding of the client's risk areas. This will result in a more effective audit. Gul et al. (2007) reiterated that when audit tenure is short, non audit fees may impair the independence of the auditor.

It is apparent that prolonged stay on an audit may result in familiarity threat. To curb this threat mandatory rotation of audit engagements have been advocated (Byrne, 2001). In the view of Kilcommins (1997), long audit tenure was perceived to impair auditor independence because it encourages auditors to become cosy in their relationships with their clients. Fairchild (2009) reiterated that the longer an auditor is, with a client, learning curve effect sets in. This will enable the auditor to detect managerial frauds more quickly; on the other hand the auditor may become sympathetic towards management thereby losing his independence.

\subsection{Non-Audit Services}

An observation of statutory pronouncements like Section 357 of the Companies and Allied Matters Act 1990 (CAMA, 1990), requires registered companies to have their financial statements audited by an independent auditor for any financial year. It can be perceived that managers are responsible for the preparation of annual accounts, designing and 
implementing internal controls, and above all ensure the smooth running of the business. Non-audit services, which constitute the source of non-audit income, may be described as any other service rendered to an audit client different from the examination of accounts and expressing a professional opinion thereof. These services are also referred to as consultancy services (Louwers et al., 2007). Ye et al. (2006), opined that the economic dependence of auditors on non-audit services, lengthy audit tenure and personal relationships built through alumni employees have contributed to the erosion of auditor independence. As such Hay et al. (2006) suggests that there exists a potential for the impairment of auditor independence in appearance when they render non-audit services. To mitigate self-interest threat which is caused by rendering non-audit services (Byrne, 2001), recommended the implementation of pronouncements like Section 202 of the Sarbanes-Oxley act of 2002, which expressly prohibits the rendering of non- audit services by statutory auditors. Abbott et al. (2003) proffered that companies with independent audit committees pay lower non-audit services fees. However Reiner \& Bent (2009) proposed that the rendering of non-audit advisory services increases quasi-rents, thereby posing a threat to auditor independence.

\subsection{Influence of Managers on Audit Fee}

In an attempt to evaluate the influence managers exert on auditors, Yost (1995) demonstrated that increased ability of managers to determine the compensation of auditors may in fact increase incentives for an auditor to maintain independence. Mitra et al. (2007) observed that there exists a significant positive relationship between diffused institutional share holdings and audit fee, and a significantly negative relationship between institutional block holder ownership and audit fee. The implication of this is that where the shares of a company are held by many investors, audit fees may very likely be determined by management, unlike where shares are held by a few, in which case it would be convenient for the few owners to meet, in other to determine the audit fee. Though it has been severally argued that non-audit fees can influence the independence of auditors, it is also likely that the influencing power of managers on the audit fee payable to the auditor may be an issue which should not be ignored. Gul (1999) recorded that the size of audit fee is a major explanatory factor for the ability of the auditor to resist the pressure of management, regardless of the provision of advisory services. Green (2006), reiterated that as businesses become more complex and the relationship between company management and company ownership becomes more problematic, the issue of auditor independence becomes more difficult. He added that as long as the auditor is subject to influence from company management, real independence remains difficult to achieve.

\subsection{Size of Audit Firm}

Salehi \& Mansoury (2009) using audit from size as a surrogate, for audit quality expressed that the size of an audit firm is an important characteristic that reflects auditor independence. Lys \& Watts (1994) were of the view that larger audit firms have better financial resources and research facilities, superior technology and more talented employees to undertake large company 
audits than do smaller audit firms. Hence big audit firms are able to resist pressure from management than smaller audit firms.

Muhammad \& Karbhari (2006) in agreement with Lys \& Watts (1994), opined that big audit firms are better able to resist management pressure in conflict situations than smaller audit firms. Contrary to these views, Emby \& Davidson (1998) opined that the size of the participant audit firm, relative to the size of the client did not exert any influence on the judgment of the auditor. Gray \& Manson (2001) in examining the effect of firm size on auditor independence, observed that while small and medium audit firms may suffer from inadequate resources, to service their large clients, the big audit firms appear as business ventures rather than professional service providers.

\subsection{Other Factors Influencing the Independence of Auditors}

In addition to the factors earlier identified, Bonu \& Kitindi (2004) identified the size of audit market and level of competition in the market of audit services as factors capable of influencing the independence of auditors. They noted that the presence of a large number of audit firms competing in a small market for audit services increased perceived auditor independences as opposed to a few firms operating in a monopoly market. In the same vein, Abu Bakar \& Ahmad (2009) suggested that the existence of an audit committee will enhance the independence of auditors.

\subsection{Nature of Auditor Independence in Nigeria}

From the foregoing the independence of external auditors appears to have generated considerable concern. In Nigeria the cry for the independence of external auditors appears not to be too different. In the world of statutory audit, audit firms can be referred as either "big players" or "small players". The classification is often based on geographical spread, staff strength and quality, and volume of audit work done.

There have been instances where auditors have not qualified their reports in respect of the business of a client. Such that, subsequent to an audit a business suddenly becomes insolvent, and acts of financial mismanagement might have gone unnoticed in previous years audit by the same audit firm. This scenario is not too strange in the business community of Nigeria. This has brought to bear the relevance of auditor independence in lending credibility to audited annual financial reports. The factors affecting the independence of auditors appear to be universal and are undoubtedly capable of affecting external auditors in Nigeria.

A substantial proportion of practicing auditors in Nigeria are members of the Institute of Chartered Accountants of Nigeria (ICAN), Association of National Accountants of Nigeria (ANAN), and Institute of Public Accountants (IPA). These professional bodies have rules guiding the conduct of members in practice. There are also specific provisions in the Companies and Allied Matters Act of 1990 that aims at safeguarding and enforcing the independence of external auditors. Section 359(6) specifically recommends companies to have an audit committee. The committee is poised to uphold the independence of auditors with respect to determining their audit fee, as well as their appointment and removal. Similar to what is obtained in developed economies, cases of corporate 
failures, mismanagement of finance and fraudulent practices of managers have caused one to wonder if the independence of statutory auditors in Nigeria is not in doubt. Aderibigbe (2005), in his research observed that in many companies across Nigeria, directors are empowered to determine audit fees of statutory auditors. This situation, no doubt may incapacitate the audit committee, and cause the auditor to undermine his independence. A World Bank report of 2004, brought to bear the inadequate adherence to auditing standards and professional ethics among statutory auditors. In addition it was pointed out that existing ethical codes were not in line with international requirements. Within the banking sector it was also noted that monitoring and enforcing mechanism are very weak. From the foregoing review of literature, this research suggests that there exists a relationship between prolonged audit tenure, audit fee, and size of audit firm on the one hand and perceived independence of auditors on the other hand. Between these two extremes exists the inter play of strength of audit committee, intensity of competition in the market for audit services and finally the enforcement powers of both regulatory and professional bodies.

\section{METHODOLOGY OF RESEARCH}

This research is based on a survey of selected companies operating in Nigeria that are listed on the Nigerian Stock Exchange. Emphasis was placed on business activities between the periods from 2000 to 2008 financial years. The research was designed to capture how selected respondents perceive the independence of auditors in Nigeria. A pilot study was conducted using five samples of a questionnaire. This was to ensure the relevancy of the data gathering instrument. The reliability of the data gathering instrument was ascertained using a test- retest correlation.

The study population used in this research comprised of auditors, shareholders, lecturers of accounting, stockbrokers, and individuals in the capacity of managers in companies listed on the Stock Exchange. The auditors were identified from the Institute of Chartered Accountants of Nigeria (ICAN) website; Stockbrokers were identified on the floor of the Nigerian Stock Exchange, while individuals in the capacity of managers were reached, at their different head offices. The accounting lectures were from the University of Lagos, University of Maiduguri, Ajayi Crowther University (Oyo) and Yaba Tech. (Lagos).

Purpose sampling technique was adopted in the selection of respondents required for this research. This technique was considered suitable because of the emphasis on the knowledge of auditor independence. However, the organizations and individuals used for the research were randomly selected from the strata of five identified from the study population. Twenty respondents were selected for each of the strata to avoid opinions gathered from being skewed. A total of one hundred respondents made up the sample size.

Primary data were extensively relied upon in the performance of this research. Questionnaires and structured interview were used to gather the primary data. Some of the instruments were administered personally while some were forwarded as attachments through emails and returned via the same method. Where physical interviews could not be conducted, telephone conversations were used. The questionnaire was designed to capture both demographic 
and topical data. The topical data were captured on a four likert scale type measure in two sections. The first section measured very weak, weak, strong and very strong opinions. The weights attached to these opinions were 1, 2, 3, and 4 respectively. The second section, measured strongly agrees, agree, disagree and strongly disagree opinions. The weights assigned to these opinions were $4,3,2$, and 1 , respectively.

In addition to the primary data, secondary data were used. The secondary data were gathered from annual reports. Some of the annual reports were obtained from the Securities and Exchange Commission on Victoria Island, some were obtained from the Nigerian Accounting Standards Board at Ikeja, while some were obtained from the different head offices in Lagos State. Annual reports used were for the periods from year 2000 to year 2008. The secondary data gathered from the annual reports include the tenure of auditors, and value of audit fees.

Both primary and secondary data were analyzed using, descriptive and inferential statistics. Inferential statistics were performed at a 0.05 level of significance using SPSS version 15.0. Kendall's Measure of Concordance was performed to measure the degree of correlation among the rankings of the respondents. This tool was used because the sample size was more than 20 and the ordinal variables were more than two. (Ifah, 1996). Hypotheses one and two were tested using Pearson product moments correlation coefficient (Đorđević et al., 2010). The Pearson correlation is measured from -1 to +1 . -1 implies an absolute negative correlation, 0 signifies no correlation and +1 indicates an absolute positive correlation. (Winks online, 2009).

\section{RESULTS AND DISCUSSIONS}

Table 1 presents a frequency distribution of the sample size used in this research. The sample was drawn from the study population. A total sample of one hundred respondents was drawn from the population.

\subsection{Test of Hypotheses}

The hypotheses purported for this research are tested below using a combination of the data gathered from responses to the questionnaire, interview and secondary data. Table 2, contains outputs of Pearson correlation coefficients, depicting the correlation between the factors influencing the independence of statutory auditors in Nigeria. From Table 2 it was observed that there exists a positive and relatively strong correlation between the responses on disclosure of income from nonaudit services and prolonged audit tenure of 0.092 . A correlation of 0.060 exists between the disclosure of non-audit income in financial statements of audit firms and the ability fee from non-audit services to deter the independence of auditors. This relationship is also positive and relatively strong. Between the opinions that audit firms should be allowed to perform non-audit services for their audit client and the need for

Table 1. Frequency distribution of respondents

\begin{tabular}{|l|c|c|}
\hline $\begin{array}{l}\text { Strata } \\
\text { Category }\end{array}$ & $\begin{array}{c}\text { Sample } \\
\text { Size }\end{array}$ & $\begin{array}{c}\text { \% of total } \\
\text { sample }\end{array}$ \\
\hline Lecturer & 20 & 20 \\
\hline Manager & 20 & 20 \\
\hline $\begin{array}{l}\text { Practicing } \\
\text { auditor }\end{array}$ & 20 & 20 \\
\hline Stockbroker & 20 & 20 \\
\hline Shareholder & 20 & 20 \\
\hline TOTAL & $\mathbf{1 0 0}$ & $\mathbf{1 0 0}$ \\
\hline
\end{tabular}


Table 2. Output of Pearson correlation coefficient

\begin{tabular}{|c|c|c|c|c|c|}
\hline & & \begin{tabular}{|c|} 
Audit firms should \\
be allowed to \\
perform non-audit \\
services for their \\
audit client \\
\end{tabular} & $\begin{array}{c}\text { Financial statements of } \\
\text { audit firms should } \\
\text { clearly disclose how } \\
\text { much is earned from } \\
\text { non-audit service } \\
\end{array}$ & $\begin{array}{c}\text { Fees from non audit } \\
\text { services can deter } \\
\text { auditor } \\
\text { independence } \\
\end{array}$ & $\begin{array}{c}\text { Prolonged audit } \\
\text { tenure can impair the } \\
\text { independence of } \\
\text { auditors }\end{array}$ \\
\hline \multirow{3}{*}{$\begin{array}{l}\text { Audit firms should be } \\
\text { allowed to perform non- } \\
\text { audit services for their } \\
\text { audit client }\end{array}$} & \begin{tabular}{|l|} 
Pearson \\
Correlation
\end{tabular} & 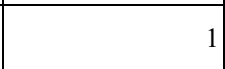 & & & \\
\hline & \begin{tabular}{|l|} 
Sig. (2- \\
tailed) \\
\end{tabular} & & & & \\
\hline & $\mathrm{N}$ & 100 & & & \\
\hline \multirow{3}{*}{$\begin{array}{l}\text { Financial statements of } \\
\text { audit firms should clearly } \\
\text { disclose how much is } \\
\text { earned from non-audit } \\
\text { service }\end{array}$} & $\begin{array}{l}\text { Pearson } \\
\text { Correlation }\end{array}$ & .067 & 1 & & \\
\hline & $\begin{array}{l}\begin{array}{l}\text { Sig. (2- } \\
\text { tailed) }\end{array} \\
\end{array}$ & .510 & & & \\
\hline & $\mathrm{N}$ & 100 & 100 & & \\
\hline \multirow{3}{*}{$\begin{array}{l}\text { Fees from non audit } \\
\text { services can deter auditor } \\
\text { independence }\end{array}$} & $\begin{array}{l}\text { Pearson } \\
\text { Correlation }\end{array}$ & -.049 & .060 & 1 & \\
\hline & \begin{tabular}{|l|} 
Sig. (2- \\
tailed)
\end{tabular} & .630 & .552 & & \\
\hline & $\mathrm{N}$ & 100 & 100 & 100 & \\
\hline \multirow{3}{*}{$\begin{array}{l}\text { Prolonged audit tenure can } \\
\text { impair the independence } \\
\text { of auditors }\end{array}$} & $\begin{array}{l}\text { Pearson } \\
\text { Correlation }\end{array}$ & .014 & .092 & $-.223(*)$ & 1 \\
\hline & \begin{tabular}{|l|} 
Sig. (2- \\
tailed)
\end{tabular} & .886 & .365 & .026 & \\
\hline & $\mathrm{N}$ & 100 & 100 & 100 & 100 \\
\hline
\end{tabular}

* Correlation is significant at the 0.05 level (2-tailed).

Source: Field survey 2010

the financial statements of audit firms to clearly disclose how much is earned from non-audit service there exist a correlation is 0.067 . However, a relatively weak but positive correlation of 0.014 was observed to be present between performance of non-audit services and prolonged audit tenure. With respect to the correlation of opinions between allowing auditors to perform nonaudit services and the effect of audit fee on independence, there exists a negative correlation of -0.049 . These correlation figures were further used to test hypotheses one and two.

\subsubsection{Test of Hypothesis One}

Ho1: There is no correlation in the perception of respondents, that fees from the performance of non-audit services can deter the independence of auditors in Nigeria.

Using the figures from the table 2 , there exist a relative but negative correlation of 0.049 between the perception that auditors should be allowed to concurrently perform non-audit services for their clients and the ability of non-audit fees to deter auditor independence. It can be inferred that the independence of auditors becomes more deterred, where non-audit services are performed concurrently and where there is no disclosure. With respect to significance, $r$ $(98)=-0.049, p>0.05$, the inference that can be drawn is that there is no significant difference in the opinions expressed by the sampled respondents. The observed correlation of opinions between prolonged audit tenure and concurrent rendering of non-audit services is 0.014 . This implies that there exists a relative positive correlation in the opinions expressed. The frequency distribution in the Appendix I(M) relating to these views showed that a cumulative of eighty three representing eighty three 
percent, of the respondents disagreed that auditors should be allowed to concurrently render non-audit services. In the same vein, Appendix I(L) depicted that all the respondents represented by a cumulative of one hundred percent of the views expressed, agreed that prolonged audit tenure could hinder the independence of auditors. At a $p$ value of 0.886 , it can be inferred that there is no significant difference in the views expressed concerning prolonged audit tenure and rendering of non-audit services. As such, it can be assumed that prolonged auditor tenure and performance of non-audit services may deter the independence of auditors.

\subsubsection{Test of Hypothesis Two}

Ho2: There is no correlation in the opinion of respondents that prolonged audit tenure can impair the independence of statutory auditors.

From the Table 2, the intercept between opinions relating to prolonged audit tenure and deterring effect of non audit fee show a negative but relative Pearson correlation of 0.223 . At this point, the $r(98)=-0.223, p<\alpha$. This implies that though the association between the two perceptions is weak, it is significant. It can be suggested therefore, that prolonged audit tenure can impair the independence of statutory auditors. In the same vain non- audit fees can also deter the independence of auditors in Nigeria.

\subsubsection{Test of Hypothesis Three}

Ho3: There is no significant agreement in the opinion of respondents on the ranking of factors capable of influencing the independence of statutory auditors in Nigeria.

From Table 3 which contains the ranking of factors capable of influencing independence of statutory auditors on Nigeria, it was observed that the most deterring factor is large audit fee. This is followed in a descending order of severity by prolonged audit tenure, size of the audit firm, intensity of competition in the market of audit services, strength of audit committee, enforcement power of professional bodies, and lastly the enforcing power of statutory bodies.

A test of correlation of opinions expressed was performed using Kendall's Measure of Concordance. The output of this test is presented in Table 4. It was deduced that the factor perceived to impair auditor independence most, was the size of audit fee. It was also observed from annual reports of selected companies that over the years the amount paid as audit fee increased. Based on the extract above it may be inferred that there

Table 3. Distribution of frequencies and means of ranks

\begin{tabular}{|l|l|l|l|l|}
\hline Ranked variables & N & Minimum & Maximum & Mean \\
\hline Prolonged audit tenure & 100 & 2.00 & 7.00 & 5.4900 \\
\hline Large audit fee & 100 & 1.00 & 7.00 & 5.7000 \\
\hline Size of audit firm & 100 & 1.00 & 7.00 & 4.3300 \\
\hline Intensity of competition & 100 & 2.00 & 6.00 & 3.8200 \\
\hline Strength of audit committee & 100 & 1.00 & 7.00 & 3.5900 \\
\hline Strength of professional bodies & 100 & 1.00 & 7.00 & 2.9200 \\
\hline Strength of regulatory bodies & 100 & 1.00 & 7.00 & 2.3300 \\
\hline Valid N (listwise) & 100 & & & \\
\hline
\end{tabular}

Source: Research Survey 2010 
Table 4.Correlation output of Kendall's measure of concordance

\begin{tabular}{|c|c|c|c|c|c|c|c|c|c|}
\hline & & & $\begin{array}{l}\text { Ranking } \\
\text { for } \\
\text { tenure }\end{array}$ & $\begin{array}{l}\text { Ranking } \\
\text { for } \\
\text { audit fee }\end{array}$ & $\begin{array}{l}\text { Ranking } \\
\text { for size } \\
\text { of } \\
\text { audit firm }\end{array}$ & $\begin{array}{l}\text { Ranking for } \\
\text { intensity of } \\
\text { competition }\end{array}$ & $\begin{array}{l}\text { Ranking for } \\
\text { strength of } \\
\text { audit } \\
\text { committee }\end{array}$ & $\begin{array}{l}\text { Ranking for } \\
\text { strength of } \\
\text { professional } \\
\text { bodies }\end{array}$ & $\begin{array}{l}\text { Ranking for } \\
\text { regulatory } \\
\text { bodies }\end{array}$ \\
\hline \multirow[t]{21}{*}{$\begin{array}{l}\text { Kendall's } \\
\text { tau_b }\end{array}$} & \multirow[t]{3}{*}{$\begin{array}{l}\text { Ranking for } \\
\text { tenure }\end{array}$} & \begin{tabular}{|l|} 
Correlation \\
Coefficient
\end{tabular} & 1.000 & & & & & & \\
\hline & & Sig. (2-tailed) & & & & & & & \\
\hline & & $\mathrm{N}$ & 100 & & & & & & \\
\hline & \multirow[t]{3}{*}{$\begin{array}{l}\text { Ranking for } \\
\text { audit fee }\end{array}$} & $\begin{array}{l}\text { Correlation } \\
\text { Coefficient }\end{array}$ & -.109 & 1.000 & & & & & \\
\hline & & Sig. (2-tailed) & .193 & & & & & & \\
\hline & & $\mathrm{N}$ & 100 & 100 & & & & & \\
\hline & \multirow{3}{*}{$\begin{array}{l}\text { Ranking for } \\
\text { size of audit } \\
\text { firm }\end{array}$} & \begin{tabular}{|l|} 
Correlation \\
Coefficient
\end{tabular} & $-.445(* *)$ & $.214(* *)$ & 1.000 & & & & \\
\hline & & Sig. (2-tailed) & .000 & .009 & & & & & \\
\hline & & $\mathrm{N}$ & 100 & 100 & 100 & & & & \\
\hline & \multirow{3}{*}{$\begin{array}{l}\text { Ranking for } \\
\text { intensity of } \\
\text { competition }\end{array}$} & $\begin{array}{l}\text { Correlation } \\
\text { Coefficient }\end{array}$ & $-.385(* *)$ & $.460(* *)$ & $.170(*)$ & 1.000 & & & \\
\hline & & \begin{tabular}{|l|} 
Sig. (2-tailed) \\
\end{tabular} & .000 & .000 & .033 & & & & \\
\hline & & $\mathrm{N}$ & 100 & 100 & 100 & 100 & & & \\
\hline & \multirow{3}{*}{$\begin{array}{l}\text { Ranking for } \\
\text { strength of } \\
\text { audit } \\
\text { committee }\end{array}$} & \begin{tabular}{|l|} 
Correlation \\
Coefficient \\
\end{tabular} & .094 & -.160 & $-.190(*)$ & $-.495(* *)$ & 1.000 & & \\
\hline & & Sig. (2-tailed) & .251 & .055 & .017 & .000 & & & \\
\hline & & $\mathrm{N}$ & 100 & 100 & 100 & 100 & 100 & & \\
\hline & \multirow{3}{*}{$\begin{array}{l}\text { Ranking for } \\
\text { strength of } \\
\text { professional } \\
\text { bodies } \\
\end{array}$} & \begin{tabular}{|l|} 
Correlation \\
Coefficient
\end{tabular} & -.121 & $-.188(*)$ & $-.234(* *)$ & .093 & $-.249(* *)$ & 1.000 & \\
\hline & & Sig. (2-tailed) & .144 & .026 & .004 & .257 & .002 & & \\
\hline & & $\mathrm{N}$ & 100 & 100 & 100 & 100 & 100 & 100 & \\
\hline & \multirow{3}{*}{$\begin{array}{l}\text { Ranking for } \\
\text { regulatory } \\
\text { bodies }\end{array}$} & $\begin{array}{l}\text { Correlation } \\
\text { Coefficient }\end{array}$ & $.283(* *)$ & $-.525(* *)$ & $-.301(* *)$ & $-.442(* *)$ & $.312(* *)$ & $-.168(*)$ & 1.000 \\
\hline & & \begin{tabular}{|l|} 
Sig. (2-tailed) \\
\end{tabular} & .001 & .000 & .000 & .000 & .000 & .047 & . \\
\hline & & $\mathrm{N}$ & 100 & 100 & 100 & 100 & 100 & 100 & 100 \\
\hline
\end{tabular}

** Correlation is significant at the 0.01 level (2-tailed).

* Correlation is significant at the 0.05 level (2-tailed).

Source: Research Survey 2010

exists some degree of association in the rankings of factors capable of affecting independence of statutory auditors in Nigeria.

\subsection{Other Findings and Observations} With respect to the independence of argument is that whether or not, whatever external auditors in Nigeria, the following observations were made in the research;

1) Directors of companies play a key role in the determination of audit fees. Though the Companies and Allied Matters Act of 1990 entrusted the audit committee with the determination of audit fee, the

Table 5. Extract of positive $p$ values from Table 4

\begin{tabular}{|lccc|}
\hline Point of Intercept & $\mathrm{k}$ value & $\mathrm{p}$ value & Comment \\
\hline $\begin{array}{l}\text { Size of audit fee and } \\
\text { strength of professional bodies }\end{array}$ & -.188 & .026 & significant correlation \\
\hline $\begin{array}{l}\text { Size of audit firm and intensity of } \\
\text { competition }\end{array}$ & .170 & .033 & significant correlation \\
\hline $\begin{array}{l}\text { Size of audit firm and strength of } \\
\text { audit committee }\end{array}$ & -.190 & .017 & significant correlation \\
\hline $\begin{array}{l}\text { Strength of professional bodies } \\
\text { and strength of regulatory bodies }\end{array}$ & -.168 & .047 & significant correlation \\
\hline
\end{tabular}


might have been decided by management is being ratified by the audit committee. It was gathered in the course of the research that most times the directors fix audit fees which are not always ratified by the audit committee. This act has brought to bear an area of weakness in the audit committee function in Nigeria.

2) Existing ethical codes appear to be obsolete. A substantial proportion of opinions expressed that existing ethical codes were no longer capable of enforcing the independence of auditor.

3) With respect to tenure, the ICAN ethical code (1998) prescribed seven years as the maximum tenure for which an auditor can audit a client consecutively. Reacting to this provision based on the questionnaire and interview, an average of four years was recommended by the sampled respondents. An observation of Appendix II revealed that some companies have maintained the same auditor for more than six years.

4) From Appendix II, a cross-sectional view of some companies listed in Nigeria, showed that many companies maintained the service of the same audit firm consecutively for many years. It was also observed the amount paid for audit fee increased from year to year.

5) It may be argued that where there is no transparency, independence may be impaired. As such it was suggested that auditors should be made to publish their financial statements. Table $\mathrm{J}$ in appendix I, showed that a total of fifty-six percent of the respondents agreed. It was further stated that at the moment audit firms in Nigeria are not body corporate and are not mandated by any law to publish their financial statements.

6) The annual reports examined did not make any specific declaration of amounts paid for non-audit services. Hence based on the disclosures in the annual reports it may be insinuate that auditors of such companies did not render professional services while acting as auditors. Where accounting services of accounting firms were used, it was observed that many of the companies used accounting firms different from the reporting auditor.

\section{CONCLUSION}

The divorce of ownership from management function in the world of business has created an aperture for custodians to exercise their best of judgment. In the present day business world, parties with stake include managers and directors (agents), stakeholders like government, employees, and providers of loan, trade creditors and potential investors. It is apparent, that as agents take decisions that are capable of influencing the business, owners, can also directly or indirectly influence the operations of the business. To checkmate decisions taken and ensure correct reporting of state of affairs of a business the audit function became a necessity especially for publicly quoted companies.

It has been expressed that credible financial information is vital to the growth of any economy, in the same vein that auditors are expected to be independent and objective in the discharge of their responsibilities. Over the years, there have been series of corporate scandals both in developed and developing economies alike. This has raised questions about the independence of the auditor in the discharge of his statutory function. To this end this research set to elucidate on the independence of external auditors in Nigeria, with emphasis on the 
opinion of respondents.

The outcome of the tests revealed that among other factors capable of deterring the independence of auditors in Nigeria, large audit fees appeared to be the most significant. It was also observed that in the opinions expressed, prolonged auditor tenure and performance of non-audit services may deter the independence of auditors. It was also noted that there are plenty of avenues for secrecy both on the part of the company being audited and the also on the part of the auditing firm.

As such, the independence of auditors is also of concern and importance in Nigeria. Large audit fees, size of audit firm, prolonged tenure have been asserted to be some of the factors capable of influencing the independence of auditors in Nigeria. It was also observed that existing laws are old and need to be reviewed to become relevant in the prevailing business world. Based on the observations of this research, there should be a law requiring auditors to publish their financial statements. In addition, existing ethical codes and laws need to be reviewed to address the contemporary challenges of engendering greater level of confidence in financial reporting and auditing.

\title{
УЧЕШЋЕ СТЕЈКХОЛДЕРА И ЊИХОВ УТИЦАЈ НА СТАТУТОРНЕ АУДИТОРЕ У НИГЕРИЈИ
}

\author{
Semiu Babatunde Adeyemi ${ }^{\mathrm{a}}{ }^{*}$ and Kehinde Opeyemi Akinniyi ${ }^{\mathrm{b}}$

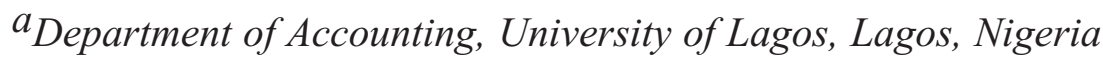

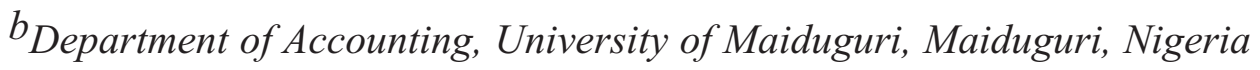

Извод

Пред крај 19тог века, јавили су се чувени случајеви корпоративних превара и финансијских проневера у тадашњим корпоративним гигантима. Серија превара је оставила утисак сумње у непристрасност екстерних аудитора на разматрање њихове функције и кредибилитету објављених финансијских извештаја. У овом светлу, ово истраживање се бави емпиријским испитивањем перцепције независности аудитора у Нигерији. Попречна анализа је спроведена која је укључивала предаваче из области аудита, аудиторе, берзанске мешетаре, деоничаре и менаџере. Примарно сакупљени подаци су се веома заснивали на њиховим ставовима. Као додатак, сакупљени су и секундарни подаци из годишњих извештаја. Сакупљени подаци су употребњени да би се одговорило на истраживачка питања и да би се тестирале хипотезе. тестирање хипотеза се заснивало на пеарсоновој корелацији и канделовој мери сагласности са нивоом значајности од 0.05. Излаз наведених тесова је показао да је најутицајнији фактор, за селектоване испитанике, висина плате и да овај фактор битно утиче на њихову независност у Нигерији. Такође је установљено да су постојећи закони застарели и потребно их је осавременити како би били примењиви.

Кључне речи: Аудитор, независност, стејкхолдер 


\section{References}

Abbott, J. L., Parker, S., Peter, F. G., \& Raghunandan (2003). An Empirical Investigation of Audit fees, Non-audit fees, and Audit Committees. Contemporary Accounting Research, 20(2) (summer):215234.

Abu Bakar, N-B., \& Ahmad, M. (2009). Auditor Independence: Malaysian accountants' Perception. International Journal of Business Management, 4(12):129141.

Abu Bakar, N-B, Rahman, A., A., \& Abdul Rashid, H., (2005). Factors Influencing Auditor Independence: Malaysian Loan Officers' Perceptions. Managerial Auditing Journal, 20(8):804-822.

Adelaja, C.O. (2009). An Evaluation of the Perception of Auditor Independence in Nigeria. Nigerian Journal of Management Studies, 10(1):45-60.

Aderibigbe, P. (2005). Auditor's Independence and Corporate Fraud. Journal of Social Sciences, 10(2):135-139.

Arnold, F. D., Bernardi, A. R., \& Neidermeyer, E. P., (1999). The Effect of Independence on Decisions Concerning Additional Audit Work: A European Perspective; Auditing. A Journal of Practice and Theory, 18 (Supplementary): 79-83

Ayvaz, E., \& Pehlivanli, D. (2010) Enterprise risk management based internal auditing and Turkey practice. Serbian Journal of Management, 5 (1):1 - 20.

Baker, C. R.,(2005). The Varying Concept of Auditor Independence, Shifting with the Prevailing Environment; retrieved from http://www.nysscpa.org, on 8/10/2009.

Byrne, P., (2001). Auditor Independence: An Update, retrieved from http://www.accaglobal.com, on 26/10/09.

Callaghan, J., Parkash, M., \& Singhal, R.
(2009); Going Concern Audit Opinions and the Provision of Non-audit Services: Implications for Auditor Independence of Bankrupt firms. Auditing. A Journal of Practice and Theory, 28(1):153-169.

Chambers 21st Century Dictionary (2002); Revised Edition.

Davis, R. L. Soo, B., \& Trompeter, G. (2000); Auditor Tenure, Auditor Independence and Earnings Management, retrieved from http://www.aaahq.org sighted on $10 / 11 / 09$.

Dictionary of International Accounting Terms (2001). Financial World Publishing Spain.

Đorđević, P., Mihajlović, I., \& Živković, Ž. (2010). Comparison of linear and nonlinear statistics methods applied in industrial process modeling procedure, Serbian Journal of Management, 5(2):189-198.

Emby, C., \& Davidson, A.R., (1998). The Effects of Engagement Factors on Auditor Independence: Canadian Evidence, retrieved from http://www.sciencedirect.com, on 18/11/2009.

Fairchild, R. (2009). Auditor Tenure, Managerial Fraud and Report Qualification: Theory and Evidence, retrieved from http://www.papaers,ssrn.com, on 10/11/2009.

Fearnley, S., \& Beattie, V., (2002). Auditor Independence and Non-Audit Services: A Literature Review, retrieved from http://www.icaew.com on 08/11/2009.

Gallegos, F., (2004). Safeguarding Auditor Objectivity : Corporate Governance Practices must not Compromise Auditor Independence, retrieved from http://www.findarticles.com, on 13/11/2009.

Geiger A. M. \& Raghunandan, K. (2002). Auditor Tenure and Audit Reporting Failures: Auditing. A Journal of Practice and Theory, 21(1): 67-78. 
Gray, I. \& Manson, S., (2000). The Audit Process, Principles, Practice and Cases, Thomson, 2nd ed. United States.

Green, L. D. (2006). Auditor Independence in Canada: A Historical Perception From Shareholders Auditors to the Modern Day Audit Committee. Accounting Perspectives, 5 (1): 37-65.

Gul, F. A., Jaggi, B., \& Krishnan, G. (2007). Auditor Independence: Evidence on the Joint Effects of Auditor Tenure and NonAudit Fees. Auditing: A Journal of Practice and Theory, retrieved from http://www.paperssrn.com, on 10/11/2009.

Gul, F.A. (1999). Size of Audit Fees and Perceptions of Auditors' Ability to Resist Management Pressure in Audit Conflict Situation, retrieved from http://www.interscience.wiley.com, on 10/11/2009.

Hay, S., \& Knechel, R., Li, V. (2006). Non-Audit Services and Auditor Independence: New Zeland Evidence. Journal of Business Finance and Accounting, 33(5-6):715-734.

Hayes, R., Dassen, R., Schilder, A., \& Wallage P. (2005). Principles of Auditing, An Introduction to International Standards on Auditing. Prentice Hall, 2nd ed. Millan.

ICAEW (2009). Auditor Independence, retrieved from http://www.icaew.com, on 08/11/2009.

Institute of Chartered Accountants of Nigeria (1995); Membership Handbook.

Institute of Chartered Accountants of Nigeria (1998); Members' Code of Conduct.

Kilcommins, M. (1997). Perceptions of Auditor Independence and the Effects on the Perceived Reliability of Financial Statements in Ireland, University of Wales (Aberystwyth): Ph. D. thesis (unpublished). Retrieved from http://www.cadour.aber.ac.uk,
10/11/2009.

Kitindi, E.G., (2004). Accounting Ethics: A Study Of Professional Independence Status Of Accounting Firms In Botswana, in Cynthia Jeffrey (ed.) Research on Professional Responsibility and Ethics in Accounting (Research on Professional Responsibility and Ethics in Accounting, Volume 9), Emerald Group Publishing Limited, pp.129-146.

Klimentchenko, D.A., (2009). Myth of Auditor Independence. University of Illinois Law Review, 4:1275-1300.

Louwers, J. T., Ramsay, J. R., Sinason, H. D., \& Strawser, R. J., (2007). Auditing and Assurance Services, McGraw-Hill Int. ed. Boston.

Lys, T., \& Watts, R. L., (1994). Lawsuits Against Auditors. Journal of Accounting Research (Supplimentary): 65-93.

McGrath S., Siegel, A., Dunfee, T. W., Glazer, A. S. and Jaenicke, H. R. (2001). A Framework for Auditor Independence, Journal of Accountancy, January, 1-4.

Millichamp, H. A. (2001). Auditing, Continuum, New York.

Mitra, S., Hossain, M. \& Deis, R.D., (2007). The Empirical Relationship Between Ownership Characteristics and Audit Fees, retrieved from http://www.springerlink.com, on $15 / 11 / 2009$.

Muhamad, Z., \& Karbhari,Y., (2006). Auditor Reputation and Auditor Independence in an Emerging Market, retrieved from http://www.papers.ssrn.com, on $12 / 11 / 2009$.

O’Connor, M. S., (2006); Strengthening Auditor Independence by Reducing the Need for it. Reestablishing Audits as Control and Premium Signaling Mechanisms. Washington Law Review, 81(3):525-594

Ojo, M. (2009). The Role of External Auditors in Corporate Governance: Agency 
Problems and the Management of Risk. Retrieved from http://mpra.ub.unimuenchen.de, on 25/11/09.

Reiner, Q. \& Bent, W. (2009). Auditor Independence and the Provision of NonAudit Services: Perceptions by German Investors. International Journal of Auditing, 13(2):141-162.

Salehi, M; \& Mansoury, A. (2009). Firm Size, Audit Regulation and Fraud Detection: Empirical Evidence from Iran. Management (spring), 4(1): 5-19.

Smith Report (2003). Reviewing Auditor Independence, retrieved from http://www.books.google.com , on 15/11/09.

Winks Online (2009). Pearson's Correlation Coefficient, retrieved from http:// www.textasoft.com, on 15/12/2009.

World Bank Report (2004). Report on the Observance of Standards and Codes (ROSC) Nigeria: Accounting and Auditing, www.worldbank.org, sighted on 16/10/2009.

Xu, Y., \& Wang J. K. (2008). Wither the Public Accounting as A Profession Historical Lessons of Auditor Independence in the USA, Journal of Academy of Business and Economics, 8(4): 127-137.

Ye, P. Carson, E. \& Simnett, R. (2006). Threats to Auditor Independence: The Impact of Non-Audit Services, Tenure and Alumni: Affiliation, retrieved from http://www.papers.ssrn.com, on 10/11/2009.

Yost, A. J., (1995). Auditor Independence as a Unique Equilibrium Response. Journal of Accounting, Auditing and Finance, (winter), 10(1):81-102. 


\section{APPENDIX I}

\section{A: Status of respondent}

\begin{tabular}{|l|l|l|l|l|l|}
\hline \multicolumn{2}{|c|}{} & Frequency & Percent & Valid Percent & $\begin{array}{l}\text { Cumulative } \\
\text { Percent }\end{array}$ \\
\hline \multirow{7}{*}{ Valid } & Lecturer & 20 & 20.0 & 20.0 & 20.0 \\
\cline { 2 - 6 } & Manager & 20 & 20.0 & 20.0 & 40.0 \\
\cline { 2 - 6 } & Practicing auditor & 20 & 20.0 & 20.0 & 60.0 \\
\cline { 2 - 6 } & Stockbroker & 20 & 20.0 & 20.0 & 80.0 \\
\cline { 2 - 6 } & Shareholder & 20 & 20.0 & 20.0 & 100.0 \\
\cline { 2 - 6 } & Total & 100 & 100.0 & 100.0 & \\
\hline
\end{tabular}

B: Strength of audit committees in Nigeria to enforce independence of auditors

\begin{tabular}{|c|c|c|c|c|c|}
\hline & & Frequency & Percent & Valid Percent & $\begin{array}{l}\text { Cumulative } \\
\text { Percent }\end{array}$ \\
\hline Valid & Very weak & 32 & 32.0 & 32.0 & 32.0 \\
\hline & Weak & 24 & 24.0 & 24.0 & 56.0 \\
\hline & Strong & 28 & 28.0 & 28.0 & 84.0 \\
\hline & Very strong & 16 & 16.0 & 16.0 & 100.0 \\
\hline & Total & 100 & 100.0 & 100.0 & \\
\hline
\end{tabular}

C: Ability of directors to influence audit fee

\begin{tabular}{|l|l|l|l|l|l|}
\hline \multicolumn{2}{|c|}{} & Frequency & Percent & Valid Percent & $\begin{array}{l}\text { Cumulative } \\
\text { Percent }\end{array}$ \\
\hline \multirow{3}{*}{ Valid } & Very weak & 6 & 6.0 & 6.0 & 6.0 \\
\cline { 2 - 6 } & Weak & 16 & 16.0 & 16.0 & 22.0 \\
\cline { 2 - 6 } & Strong & 53 & 53.0 & 53.0 & 75.0 \\
\cline { 2 - 6 } & Very strong & 25 & 25.0 & 25.0 & 100.0 \\
\cline { 2 - 6 } & Total & 100 & 100.0 & 100.0 & \\
\hline
\end{tabular}

D: Power of the auditor to express a qualified opinion

\begin{tabular}{|c|c|c|c|c|c|}
\hline & & Frequency & Percent & Valid Percent & $\begin{array}{l}\text { Cumulative } \\
\text { Percent }\end{array}$ \\
\hline \multirow[t]{5}{*}{ Valid } & Very weak & 13 & 13.0 & 13.0 & 13.0 \\
\hline & Weak & 23 & 23.0 & 23.0 & 36.0 \\
\hline & Strong & 40 & 40.0 & 40.0 & 76.0 \\
\hline & Very strong & 24 & 24.0 & 24.0 & 100.0 \\
\hline & Total & 100 & 100.0 & 100.0 & \\
\hline
\end{tabular}


E: Effect of audit firm size on the independence of the auditor

\begin{tabular}{|l|l|l|l|l|l|}
\hline \multicolumn{2}{|c|}{} & Frequency & Percent & Valid Percent & $\begin{array}{l}\text { Cumulative } \\
\text { Percent }\end{array}$ \\
\hline \multirow{7}{*}{ Valid } & Very weak & 6 & 6.0 & 6.0 & 6.0 \\
\cline { 2 - 6 } & Weak & 18 & 18.0 & 18.0 & 24.0 \\
\cline { 2 - 6 } & Strong & 54 & 54.0 & 54.0 & 78.0 \\
\cline { 2 - 6 } & Very strong & 22 & 22.0 & 22.0 & 100.0 \\
\cline { 2 - 6 } & Total & 100 & 100.0 & 100.0 & \\
\hline
\end{tabular}

F: Ability of professional bodies to enforce independence ofpracticing members

\begin{tabular}{|l|l|l|l|l|l|}
\hline \multicolumn{2}{|c|}{} & Frequency & Percent & Valid Percent & $\begin{array}{l}\text { Cumulative } \\
\text { Percent }\end{array}$ \\
\hline Valid & Very weak & 13 & 13.0 & 13.0 & 13.0 \\
\cline { 2 - 6 } & Weak & 28 & 28.0 & 28.0 & 41.0 \\
\cline { 2 - 6 } & Strong & 49 & 49.0 & 49.0 & 90.0 \\
\cline { 2 - 6 } & Very strong & 10 & 10.0 & 10.0 & 100.0 \\
\cline { 2 - 6 } & Total & 100 & 100.0 & 100.0 & \\
\hline
\end{tabular}

G: Independence of "big" audit firms in Nigeria

\begin{tabular}{|l|l|l|l|l|l|}
\hline \multicolumn{2}{|c|}{} & Frequency & Percent & Valid Percent & $\begin{array}{l}\text { Cumulative } \\
\text { Percent }\end{array}$ \\
\hline \multirow{3}{*}{ Valid } & Very weak & 13 & 13.0 & 13.0 & 13.0 \\
\cline { 2 - 6 } & Weak & 16 & 16.0 & 16.0 & 29.0 \\
\cline { 2 - 6 } & Strong & 59 & 59.0 & 59.0 & 88.0 \\
\cline { 2 - 6 } & Very strong & 12 & 12.0 & 12.0 & 100.0 \\
\cline { 2 - 6 } & Total & 100 & 100.0 & 100.0 & \\
\hline
\end{tabular}

H: Independence of "small" audit firms in Nigeria

\begin{tabular}{|l|l|l|l|l|l|}
\hline \multicolumn{2}{|c|}{} & Frequency & Percent & Valid Percent & $\begin{array}{l}\text { Cumulative } \\
\text { Percent }\end{array}$ \\
\hline Valid & Very weak & 25 & 25.0 & 25.0 & 25.0 \\
\cline { 2 - 6 } & Weak & 47 & 47.0 & 47.0 & 72.0 \\
\cline { 2 - 6 } & Strong & 21 & 21.0 & 21.0 & 93.0 \\
\cline { 2 - 6 } & Very strong & 7 & 7.0 & 7.0 & 100.0 \\
\cline { 2 - 6 } & Total & 100 & 100.0 & 100.0 & \\
\hline
\end{tabular}

I: Intensity of competition in the market of audit services in Nigeria

\begin{tabular}{|l|l|l|l|l|l|}
\hline \multicolumn{2}{|c|}{} & Frequency & Percent & Valid Percent & $\begin{array}{l}\text { Cumulative } \\
\text { Percent }\end{array}$ \\
\hline \multirow{4}{*}{ Valid } & Very weak & 12 & 12.0 & 12.0 & 12.0 \\
\cline { 2 - 6 } & Weak & 26 & 26.0 & 26.0 & 38.0 \\
\cline { 2 - 6 } & Strong & 58 & 58.0 & 58.0 & 96.0 \\
\cline { 2 - 6 } & Very strong & 4 & 4.0 & 4.0 & 100.0 \\
\cline { 2 - 6 } & Total & 100 & 100.0 & 100.0 & \\
\hline
\end{tabular}




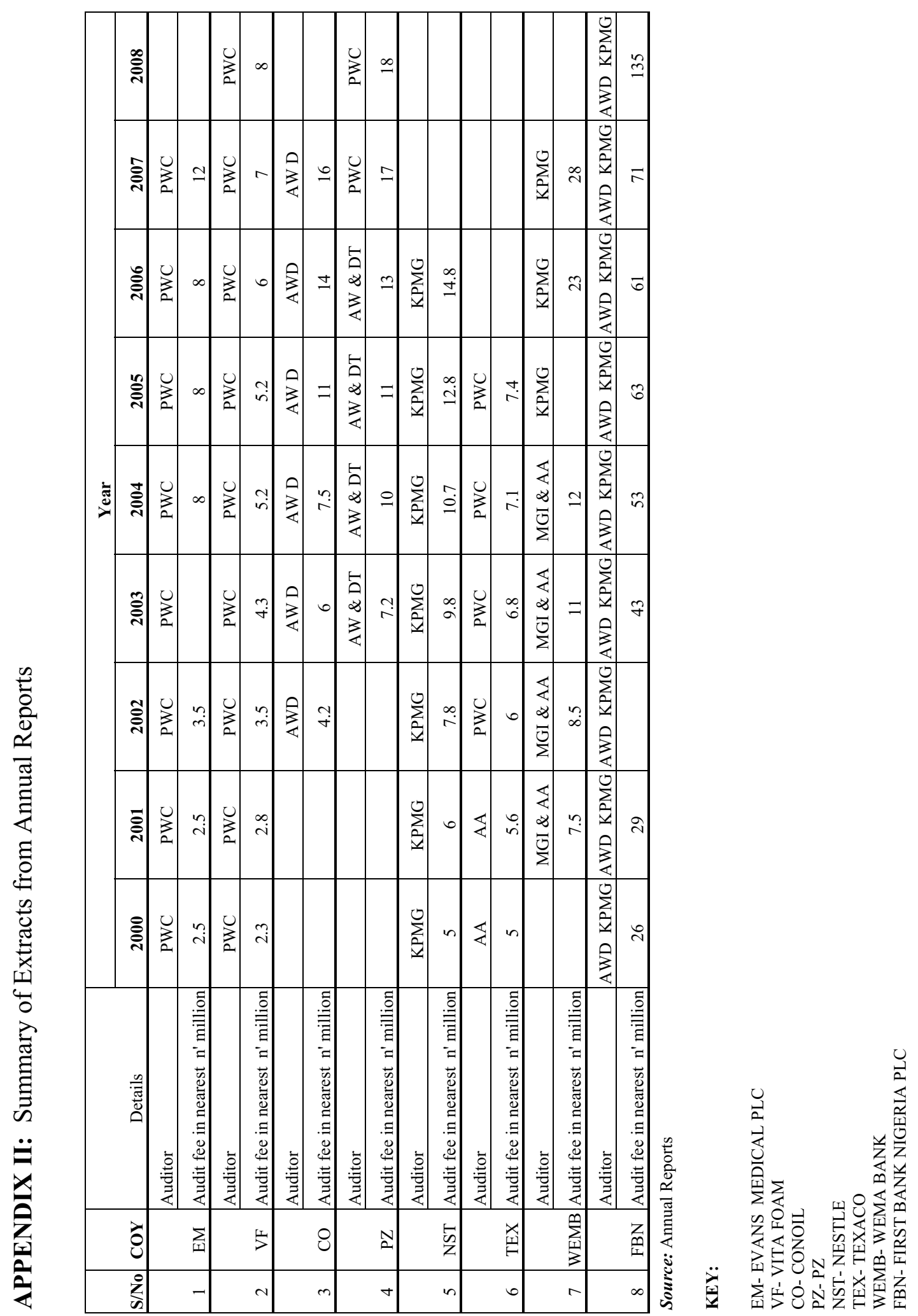


J: The published financial statements of audit firms should clearly disclose how much is earned from non-audit service

\begin{tabular}{|l|l|l|l|l|l|}
\hline \multicolumn{2}{|l|}{} & Frequency & Percent & Valid Percent & $\begin{array}{l}\text { Cumulative } \\
\text { Percent }\end{array}$ \\
\hline Valid & Very weak & 14 & 14.0 & 14.0 & 14.0 \\
\hline & Weak & 25 & 25.0 & 25.0 & 39.0 \\
\hline & Strong & 44 & 44.0 & 44.0 & 83.0 \\
\hline & Very strong & 17 & 17.0 & 17.0 & 100.0 \\
\hline & Total & 100 & 100.0 & 100.0 & \\
\hline
\end{tabular}

K: Fee from non audit services can deter auditor independence

\begin{tabular}{|c|c|c|c|c|c|}
\hline & & Frequency & Percent & Valid Percent & $\begin{array}{l}\text { Cumulative } \\
\text { Percent }\end{array}$ \\
\hline \multirow[t]{3}{*}{ Valid } & Agree & 37 & 37.0 & 37.0 & 37.0 \\
\hline & Strongly agree & 63 & 63.0 & 63.0 & 100.0 \\
\hline & Total & 100 & 100.0 & 100.0 & \\
\hline
\end{tabular}

L: Prolonged audit tenure can impair the independence of auditors

\begin{tabular}{|l|l|l|l|l|l|}
\hline \multicolumn{2}{|c|}{} & Frequency & Percent & Valid Percent & $\begin{array}{l}\text { Cumulative } \\
\text { Percent }\end{array}$ \\
\hline \multirow{3}{*}{ Valid } & Agree & 55 & 55.0 & 55.0 & 55.0 \\
\cline { 2 - 6 } & Strongly agree & 45 & 45.0 & 45.0 & 100.0 \\
\cline { 2 - 6 } & Total & 100 & 100.0 & 100.0 & \\
\hline
\end{tabular}

M: Audit firms should be allowed to perform non-audit services for their audit client concurrently

\begin{tabular}{|l|l|l|l|l|l|}
\hline \multicolumn{2}{|c|}{} & & & & $\begin{array}{l}\text { Cumulative } \\
\text { Percent }\end{array}$ \\
\hline \multirow{3}{*}{ Valid } & Ferequency & Percent & Valid Percent & 32.0 \\
\cline { 2 - 6 } & Weak & 32 & 32.0 & 32.0 & 33.0 \\
\cline { 2 - 6 } & Strong & 51 & 51.0 & 51.0 & 93.0 \\
\cline { 2 - 6 } & Very strong & 10 & 10.0 & 10.0 & 100.0 \\
\cline { 2 - 6 } & Total & 7 & 7.0 & 7.0 & \\
\hline
\end{tabular}

Source: Field Survey, 2010 